DOI: 10.2478/ausfm-2019-0016

\title{
Television and Video Screens in Filmic Narratives: Medium Specificity, Noise and Frame-Work
}

\author{
Andrea Virginás \\ Sapientia Hungarian University of Transylvania (Cluj-Napoca, Romania) \\ E-mail: virginas.andrea@kv.sapientia.ro
}

\begin{abstract}
The paper discusses pertinent aspects of the screen as a device of framing and re-ordering. Television and video screens introduced in filmic diegesis are attributed three main functions (spatial, temporal, and topical re-ordering) and are related to the relationships Gerard Genette establishes between first-order narrative and metadiegetic levels (1987), as well as to Lars Elleström's extracommunicational and intracommunicational actual and virtual spheres (2018). The visibility through noise of the televisual and of the video media is theorized based on Sybille Krämer's media theory (2015) and three pre-digital arthouse films: Videodrome (David Cronenberg, 1984), Irma Vep (Olivier Assayas, 1996), and Lost Highway (David Lynch, 1997). ${ }^{1}$
\end{abstract}

Keywords: cinematic screen, electronic screen, diegesis, noise, narrative levels.

\section{Screens (and Frames), and Electronic Medium Specificity}

Friedrich Kittler, among so many others, has been right in drawing attention to the diminishing chances of separating film, video, or television with the advent of the digital. "If the historical synchronicity of film, phonograph, and typewriter in the early twentieth century separated the data flows of optics, acoustics and writing and rendered them autonomous, current electronic technologies are bringing them back together; in the future a total connection of all media on a digital base will erase the very notion of a medium" - summarizes Kittler's thoughts John Johnston (1997, 5-6). However, our present is still characterized by the culturally, and perhaps also cognitively funded differences among the

1 This work was supported by a grant of the Ministry of National Education, CNCS - UEFISCDI Romania, project number PN-III-P4-ID-PCE-2016-0418. 
mentioned technical and electronic media. According to the main argument of this article, media differences conceived in this manner are also sustained by such constructions in the diegetic worlds of films where these various media, indexed by corresponding screens, are present as apparently afilmic, but actually profilmic objects with serious functions in the narrative development. This argument may be conceived of as a consequence of the author's previous analysis (Virginás 2018) which attributed to electronic screens embedded in the diegetic worlds of films the role of training the film viewers for experiences of expanded and fragmented cinema (Gaudreault and Marion 2015) as they force the audience to constantly shift between the actual cinematic screen conventions and the mental screen (Odin 2016) of smaller formats.

Friedrich Kittler emphasizes that storage and information manipulation are intertwined with transmission in the case of media as "there are, first of all, media of transmission such as mirrors; secondly, storage media, such as film; and thirdly [...] machines that manipulate words or figures themselves" $(1997,132-$ 133). Within this context, screens may be described as framed spectacles related to electronic and technical media: film, video, television, and computer or mobile (phone). These media not only produce or store, but also distribute content, in accordance with Lars Elleström's definition of a technical medium: "the notion of a technical medium should consistently be understood not as a technical medium of production or storage but of 'distribution' in the precise sense of disseminating sensory configurations" $(2014,14)$. This definition allows one to fix the screens in the moment of "distributing/disseminating sensory configurations" according to the various media(l) apparatuses they are the endpoint of. This characteristic of electronic screens as part of complex media(l) apparatuses allows for both smooth media representation ${ }^{2}$ on their part, or, on the contrary, a non-neutralization of the medium/media involved, making them "visible" through glitches and noises. This is an idea inspired by Sybille Krämer's media theory (2015), where the constant neutralizing of any medium is suggested for the sake of the message to be revealed: "the message is [...] considered primary, while the medium itself is secondary; it neutralizes itself, becomes invisible and disappears in its (noisefree) use" (Kramer 2015, 35). Before presenting a number of close readings of smooth media representation or, on the contrary, noisy non-neutralization of a medium through diegetic electronic screens - aiming to support the general

2 "Media representation is at hand whenever a medium presents another medium to the mind. A medium, which is something that represents, and becomes itself represented" as in ekphrasis (Elleström 2014, 15). 
hypothesis that medium specificity is being sustained thus - an overview of the modes of embedding electronic screens in films' diegetic worlds is to follow first.

Three main functions may be attributed to the interweaving of electronic screens (with)in filmic diegeses and with respect to the happenings of the firstlevel, actual diegetic happenings: a temporal, a spatial, and a topical re-ordering function. As for the temporal function of such diegetic electronic screens: their presence may suggest that the past, or indeed, in a medium-specific discourse, slices of film history are safely contained on and by screens that may be put in function when we need them. This is what happens to "classical Hollywood," for example, when an undressing Bette Davis washing her make-up in Joseph L. Mankiewicz's 1950 All About Eve is intercalated as a televisual screenic image already in the credit sequence of Pedro Almodóvar's 1999 All About My Mother; or when the final love or death duel from Billy Wilder's 1944 Double Indemnity appears in the same manner in Brian de Palma's 2000 Femme Fatale; or when a moving image excerpt from a 1940s Veronica Lake-movie is projected on the wall in Curtis Hanson's 1996 L.A. Confidential (Virginás 2007). This type of usage of diegetic electronic screens may be characterized according to the timebased classification of Lev Manovich in The Language of New Media, where he categorizes screens based on their relationship with diegetic time (as it were). From that standpoint "the classical screen displays a static, permanent image; the dynamic screen displays a moving image of the past; and finally, the real-time screen shows the present" (Manovich 2001, 103). Conserving film-historically charged moments on "the dynamic screens" of television sets or within the beams framed by celluloid projectors might seem as an accidental choice compared to more genre-bound constellations such as detectives searching for data and traces on diegetic electronic screens. These typical figures of search may employ Manovich's classical screen regime, as if these television or computer screens were (functioning) as paintings: this is what happens in the 1984 Blade Runner when Deckard scans and analyses the photograph he found in the apartment of replicant Leon Kowalski. However, the same screen transforms onto Manovich's dynamic screen open for different temporalities (and thus spatialities), not just the past, as detection advances in both Blade Runners (the latter from 2017, dir. Denis Villeneuve). Meanwhile, the 2002 Minority Report (dir. Steven Spielberg) opens with a Manovichian "real-time screen" that mirrors the real-time events of pre-crime diegetic detection events (see Virginás 2014 for further details).

Evidently, these electronic screens, from video to mobile digital screens, might encage their content not only in time, but also, quite literally, in space. The 
specificity of the film/cinematic screen compared to other types of screens, such as computer monitors, becomes even more evident if we evoke the comparison of off-screen spaces in the case of film, and respectively computer interface. Per Persson observes that in cinema, which he also names as "realistic space" in contrast to the "abstract space" of interfaces, "the space 'stretches out' beyond the frame; concepts of left-right/up-down off screen space are meaningful; objects look and behave more or less like everyday objects. However, many (if not most) interfaces are not realistic in this sense. [...] The space off screen (right-left or below-above) does not contain anything in particular and does not trigger any particular off-screen space expectations. Everything of interest is contained within the frame. The landscape does not 'stretch out' into the distance in any direction" (Persson 1999, 204). Thus, the particular moments of detecting figures searching through and with the help of diegetic electronic screens may also be regarded as full with the tension of resolving the opposition between the "realistic screen of cinema," where off-screen space is full with meaning, and the "abstract space of interfaces," where off-screen is devoid of meaning. This aspect has been described from another angle by Vivian Sobchack, who observed that "ungrounded and uninvested as it is, electronic presence has neither a point of view nor a visual situation, such as we experience, respectively, with the photograph and the cinema" $(2000,80-81)$. This tension between meaningful cinematic off-screen space and computer presence ungrounded outside the frame of screen is at the heart of recent digital melodramas, where men exist in traversable "real" cinematic spaces while digital/computer screenic presences are feminized. Thus, the low possibilities of actual romance define narrative outcome as in the case of Theodore Twombly's meeting Samantha, the operation system in Spike Jonze's 2013 Her, or Caleb and Nathan's falling for the artificial intelligence's bluish wires in Alex Garland's 2015 Ex Machina (see Virginás 2017).

The topical re-ordering function of embedded diegetic electronic screens is dependent on the fact that "an emphasized boundary" along the "rectangular frame" is evident (Manovich 2001, 112), separating the cinematic, first-level diegetic space and the non-cinematic screenic interface. It needs to be stressed that what I call diegetic electronic screens, these a- and profilmic objects, are "vertical viewing dispositifs" (Strauven 2016, 144), concentrating all the above qualities of the framed view, to which Roger Odin adds that "the fact of framing helps us to see better and make the world be seen" $(2016,183)$. Considering it one type of parergon, like the title or a signature on a painting, or indeed the clothing on a statue, Jacques Derrida also writes of the frame that it "is the decisive structure 
of what is at stake, at the invisible limit to (between) the interiority of meaning [...] and (to) all the empiricisms of the extrinsic" $(1987,61)$. In The Truth of Painting, Derrida repeatedly returns to conditions of consistency for the parerga, and consequently for the frame, and his observations may be extrapolated to the case in point of the diegetic electronic screens. "Parerga have a thickness, a surface which separates them not only (as Kant would have it) from the integral inside, from the body proper of the ergon, but also from the outside, from the wall on which the painting is hung, from the space in which statue or column is erected, then, step by step, from the whole field of historical, economic, political inscription in which the drive to signature is produced." (Derrida 1987, 61.) Lev Manovich reflects upon this aspect too when highlighting the fundamental characteristic of the screen and its frames: namely that it "separates two spaces that have different scales - the physical and the virtual. Although this condition does not necessarily lead to the immobilization of the spectator, it does discourage any movement on her part" (2001, 112, emphasis in the original). The author's previous analyses show that electronic screens within the European-type filmic diegeses - characterized by adhering to conventions of (hyper)realism, nonhypermediation and character-centred storytelling - in a digital era are used not only as props, but as frames that re-order and aestheticize levels of reality (Odin 2016), while focusing, in a hypnotic manner, the viewers' attention (Chateau 2016) on traumatic memories related to usually female characters, and consequently to the collectivities they represent in the respective diegetic worlds (see Virginás 2018 for further details).

Though not pursued in this article, it needs to be signalled that this kind of analysis might be subsumed under the larger problematic of what Gerard Genette defines as "the main types of relationships that can connect the metadiegetic narrative to the first narrative, into which it is inserted" $(1983,232)$. In this case, the embedded electronic screens obviously carry metadiegetic content with respect to the first (cinematic) narrative diegesis. Genette delimits on the one hand "direct causality between the events of the metadiegesis and those of the diegesis, conferring on the second narrative an explanatory function" $(1983,232)$, and this is evidently the case with the above described temporal re-ordering function attributed to the diegetic electronic screens. The other relationship that Genette conceives of between the first narrative and the metadiegetic narrative "consists of a purely thematic relationship, therefore implying no spatio-temporal continuity between metadiegesis and diegesis: a relationship of contrast [...] or of analogy" (1983, 233). The spatial as well as the topical re-ordering functions that I have 
attributed to diegetic electronic screen in cinematic diegeses comply with these categories of Genette. The third type of relationship is described in Narrative Discourse: An Essay in Method as "involve[ing] no explicit relationship between the two story levels: it is the act of narrating itself that fulfills a function in the diegesis, independently of the metadiegetic content - a function of distraction, for example, and/or of obstruction" (Genette 1983, 233). While the narratological roots of an apparently intermedial analysis have become evident, the different paths of interpretation enabled by these different methods also come forward: the technical-electronic media connoted by the diegetic screens and the cinematic screen do not cease to mediate their content, and only at the price of serious medium-typical noise/glitch can they arrive in the state described by Genette, when "only the act of narrating itself" $(1983,233)$ is in function.

\section{Noise on the Threshold between Mediation and Representation}

To such "an archaeology of the screen and the frame" (Elsaesser 2016, 112) and to the insights gained up to now as to the role of non-cinematic, diegetic, electronic screens in filmic diegetic world basically integrated in arthouse aesthetics and authorial oeuvres, further refinements could be added due to a temporal comparison introduced between the 1990s and, respectively, the 2000s. In the first mentioned decade Gaudreault and Marion's "hegemonic cinema screen” (2015, 11) has been evidently challenged by the duo of the television screen and the video monitor, much before digital, mobile, and even post-digital variants have transformed our "screen environments," generating what Giuliana Bruno names "the ever-present environmental screen-effect within which we now live" (Bruno $2014,102)$. This is a process that we can trace from the 1980s/1990s' television and video screens as embedded in David Cronenberg's 1983 Videodrome, Olivier Assayas's 1996 Irma Vep and David Lynch's 1997 Lost Highway to 21 ${ }^{\text {st }}$-century, post-digital sensibilities of recreating and/or simulating non-digital image screens as in Lynch's 2007 Inland Empire, Assayas' 2014 Clouds of Sils Maria, Cronenberg's 2014 Maps to the Stars or Denis Villeneuve's 2015 Arrival. This line of analysis luckily blends with the post-2015 resurgence of interest in screens and their theories, while being an appendix to Gaudreault and Marion's theory of how filmic diegesis exists and exerts its influence in the digital, and even in the post-digital era, of which Florian Cramer observes that "it is an approach to digital media that no longer seeks technical innovation or improvement, but 
considers digitization something that already happened and can be played with" (Cramer 2013).

Through not masking their "mediate conditions of working” (Rubio Marco 2016, 222), ${ }^{3}$ but rather highlighting what Elleström names "the physical realization of entities (with material, sensorial, and spatiotemporal qualities, and semiotic potential)" $(2014,12)$, the digital screenic ideal of immediacy is definitely challenged in many of the sequences I have been examining. Sybille Krämer's media theory, in her 2015 Medium, Messenger, Transmission: An Approach to Media Philosophy, centred on the figure of the messenger and theorizing (the) medium as such is called forth therefore. Krämer presents the following sensual examples to formulate one of her main theses: "we hear not vibrations in the air, but rather the kettle whistling; we see not light waves of the yellow colour spectrum but rather a canary; we hear not a CD, but rather music; and the cinema screen 'disappears' as soon as the film grips us. The smoother media work, the more they remain below the threshold of our perception" $(2015,35)$. These instances, where diegetic electronic screens are scattered within the examined filmic diegetic spaces are non-neutralizing for the medium/media involved, making them "visible" according to the Krämerian model and demonstrating their non-noise-free use primarily for the actual viewer, and occasionally for the diegetic spectator, too. Since, as Anthony Enns observes: "the danger always exists that the medium might introduce a degree of noise or interference into the act of transmission by making his presence felt instead of remaining neutral and transparent, such as when the devil attempts to manipulate listeners, when the psychoanalyst falls in love with his patient" $(2015,17)$. Thus, the message that should be transmitted through the given medium/media is becoming obliterated, losing its contours and precision, while the specific technical and electronic medium of television and/ or video involved is attributed a medium specificity always contrasted with the full-scale representational possibilities of the cinematic screen and medium.

David Cronenberg's 1984 film Videodrome sets up the rules of its diegetic electronic screen use aiming at making the medium visible and filling it with noises of all kinds already in the introductory credit sequence. First, animated letters fill the cinematic screen, their candy colours and rudimentary design disturbing, evidently, the cinematic immersion, and a shortly visible screenic

3 'Every screen is, in a way, a 'masking screen,' for it tries to mask the mediate (that is, not immediate) conditions of its working, and to show that the history of screens is the history of the naturalization of that mediation to the point at which screens lose their excess baggage ('masking') in order to become just 'screens', allegedly enabled to show every bit of the reality they refer to." (Rubio Marco 2016, 222.) 
glitch of a black-and-white nonfigurative formation informs the actual viewer that the sensible surface of this screen does not bear messages as usual/as normative. The analogue/cathodic television screen's first decipherable message in Videodrome is, as suggested previously, a female figure (Virginás 2018), who appears before a background composed of at least seven different frames that circumscribe differently scaled, (non-electronic) framed screens bearing different messages. This female figure is Bridey, the secretary of Videodrome's main male character, Max Renn, and she remains a diegetic electronic screen presence throughout this introductory sequence, with the television's black screen frames visible while she addresses her boss with a wakeup message of organizing work.

Bridey (the actress Julie Khaner) is a messenger/medium, whose materiality and embodiment should be less important than the message she has to get through to Max, with the imperative of an establishing shot also hanging over her head: she has to give us the basic time-space coordinates and inform us of the positioning within the narrative world. Interestingly, Bridey disregards the televisual screenic rules of composed body posture and reserved talking mode as she is overreacting, smiling, leaning forward, and thus protruding out of her televisual frame. Her monologue is evidently self-conscious ("I am your girl Friday," she says), thus introducing further moments of noise into the televisual medium's screen. Already in these introductory credit sequences we are presented with what Sybille Krämer names “the medium's inherent features" $(2015,31)$ : television's specific framing techniques, the visual glitches and its two-dimensional, flat liveness. It is through these latter characteristics that Bolter and Grusin identify the medium specificity of television, based on Marshall McLuhan and Raymond Williams's ideas: "McLuhan and Williams, media critics with very different agendas, have both suggested that the poorer resolution or different lighting robs television of visual depth [...]. It seems fair to say that the flatness and coarseness of the traditional televised image did make it harder to remediate the perspective techniques of photography and film and that perceptual transparency has therefore been a less successful strategy for television than for these other media" (Bolter and Grusin 2000, 186-187). Besides television's "inherent features," "its functional logic," which "only takes effect when media are in use, "its (media) performance" (Kramer 2015, 31) - is also represented, but also transmediated: in this case, Bridey being recorded by a small video camera becomes in-built within the screenic panorama.

All this is performed in a multiply nested, multimedial narrative context: the cinematic screen showing Videodrome and its actual viewer(s) encapsulates a diegetic television screen and its diegetic viewer in the person of Max Renn, 
and the latter apparatus contains a framed image of Birdey and the camera-eye watching and filming her. This process of various layers of remediation may be situated among what Elleström names "a perceived actual sphere" (2018, 432): Bridey's message being recorded, furthermore, the television set's apparatus as situated in the diegetic world, and finally, the cinematic(ally modelled) experience of watching Videodrome. This multimodal layering of remediations may be identified as a subcase of what Elleström describes as "the mise-enabyme" structure activating the constitution of the three spheres while human communication happens. "Intracommunicational virtual spheres are formed by perceived actual spheres and by other, extracommunicational virtual spheres that are in turn formed by perceived actual spheres and by other, extracommunicational virtual spheres ad infinitum." (Elleström 2018, 433.) The "intracommunicational virtual sphere" of Bridey and Max's televised meeting is interrelated with Bridey's "extracommunicational virtual sphere" as she is recorded by the camera, as well as "the extracommunicational virtual sphere" that is reaching out towards the actual (cinematic) viewer of Videodrome, for whom, in a countermove, the whole cinematic diegetic screen constitutes something that I would call a mixture of "a perceived actual sphere," "an extracommunicational virtual sphere," and "an intracommunicational virtual sphere.”

The backtracking, circular cinematic camera is focusing on the black television set, whose screen should be framed by a perpendicularly standing human eye/ cinematic camera according to televisual rules, in an oblique, strange angle, connoting noise/glitch in the televisual medium. Consequently, fragments of the diegetic space are made visible which are hardly identifiable for the cinematic audience, introducing further moments of noise, but this time in the cinematic apparatus. When one of the first credit intertitles ("Starring James Woods") is superimposed on the cinematic screen, a collision of televisual and cinematic media is performed. Its effects are fully amplified in the "Deborah Harry" shot, where the rock star postulates pop music culture too, with all the before mentioned media noises active, and recalling Elleström's mise-en-abyme ad infinitum between "a perceived actual sphere," "an extracommunicational virtual sphere," and "an intracommunicational virtual sphere" $(2018,433)$. The analysed opening sequence from Videodrome ends with a cinematic close-up on Max Renn's hand/ watch and his face, while the television screen in the background recedes, its texture and sensible surface losing features, becoming a simple patch of colour in the diegetic space. As Krämer formulates: "at the same time that media bring something forth, they themselves recede into the background; media enable 
something to be visualized, while simultaneously remaining invisible" $(2015,31)$.

The first intermedial inclusion of the video cassette player and the television screen into the cinematic diegetic world is, once again, happening quite early as far as screen time is concerned in Olivier Assayas's 1996 Irma Vep. The HongKong action film star Maggie Cheung arrives to the headquarters of the Paris film production company, and after a minor hassle she is accompanied by the producer to the director of the film she is supposed to shoot, a remake entitled Irma Vep. Maggie and the producer leaving the headquarters are shown through a handheld camera, from which there is an abrupt cut to a visibly differently coloured image with very different resolution, too. An opposition is thus created between the invisible, noise-free functioning of the cinematic medium and the non-seamless performance of the video/televisual image. The daylight and fullspectrum colour-world of the cinematic narrative, including Maggie's shirt-collar designed as an actual colour spectrum, and the moving human bodies filmed through a moving-eye-level camera - also through a glass pane -, signal a medially conscious system of audiovisual representation, while highlighting the validity of Sybille Krämer's emphasis on the requirement that media need to be material and transparent at the same time. "Media are indeed bound to materiality, but their transparency is practically required: air, water or crystals are thus the most favourable materials for media of perception.” (Krämer 2015, 32.)

This sequence is followed by a fixed view image, in which zooming out is combined with an object/a bullet flying towards the perspectival centre of the actual cinematic viewer, with a low resolution, interior image of black-andwhite dominance, sometimes turning into a bluish shade, especially in closeup structures. Then the static existence of the fixed camera is contrasted by energetically moving human bodies and unstoppably flying objects (bullets, weapons), matched by high-pitched soundtrack, and a Chinese/English subtitling becoming visible too, alluding to the international theatrical distribution. In this context, the decrease in image quality may be identified as a Krämerian (media) noise that makes the medium - in this case video and television image/apparatus - apparent/perceivable to the actual cinematic viewer: "only noise, dysfunction and disturbance make the medium itself noticeable” (Krämer 2015, 31).

The previously described blue martial arts excerpt in Assayas's film joins a further shot characterized by full-spectrum, daylight colours in full resolution, presenting a formally dressed male figure who pushes a button on a remote control pointed towards the cinematic camera and the actual film viewers. The male figure is director Rene Vidal (a memorable performance of Jean-Pierre Léaud), 
meeting for the first time the lead actress of his next movie, a contemporary, Hong-Kong martial arts-style adaptation of a cult, classical French movie, Louis Feuillade's 1913/1915 Les Vampires, this time re-made for television.

As we hear Vidal's off-screen words narrating his discovery of Maggie's cinematic mastery in what he names "a very very cheap cinema in Marrakech," the camera shows us video cassettes with oriental/Chinese inscriptions, scattered on the floor, thematizing the video medium in a moment of media representation. But, as we have already seen, video image is also transmediated ${ }^{4}$ in Assayas's film through the low-resolution and slowed down clips that have a colour palette usually reduced to black-and-white and a third, complementary shade (blue, grey, or animation overimposed), being excerpts from a-filmic Maggie Cheung's previous martial films made in Hong Kong. Vidal's contouring the background of his conception of Les Vampires' current adaptation for television with “a modern-day Irma Vep" concludes by his taking one of the video cassettes in his hand, with the gesture shown for a long time by the camera, highlighting its importance, as well as associating the video medium with an outdated, superfluously pompous French director.

As Vidal, the director, pushes the cassettes in the video-player, we encounter the same circular camera-movement that was employed in Videodrome in order to include further fragments of the diegetic space. There: the room's furniture and Max Renn sleeping on the couch, covered in a right-moving, backtracking move, here: the room's other half enlightened by the window and Maggie watching Vidal's television screen covered through a left-moving gliding move. Contrasting video/televisual two-dimensional flatness with cinematic possibilities of going through space in three dimensional moves is also performed, as Maggie's gracious protruding profile will match the next shot formally, where 1913 Irma Vep, in her black catsuit, leans to the right in a similar pattern. The black-and-white content of the television screen showing a video cassette's muted content is followed, without any transition, by a colourful image with many objects in it, Arabic/oriental-type music making it even more complex. This is the costume shop ("for hookers" as the production assistant outs it) where Maggie will appear wearing the black latex catsuit, having started her transition towards embodying legendary Irma Vep.

In a later memorable scene we see Maggie, made-up and dressed as Irma Vep, being interviewed by a two-member, male television crew about Asian film

$4 \quad$ Refining with great conceptual precision David Jay Bolter and Richard Grusin's all-encompassing "remediation," Elleström's transmedial remediation refers to such instances when "equivalent sensory configurations [...] are mediated for a second (or third or fourth) time and by another type of technical medium," for example "the poem on the page is later heard when it is transmediated by a voice" (Elleström 2014, 14). 
culture and her own position in it. The scene starts by Maggie being followed by a left-gliding, horizontal cinematic camera as she is sitting in the diegetic video camera's view, while the reporter is looking at a small video monitor positioned to the left, exclaiming "she's gorgeous." According to Roger Odin, "the notion of a mental screen corresponds to physical screens (cinema, television) that have become mental spaces" $(2016,185)$, and it is the actual viewer's capacity to configure his/her mental screen for smaller formats that is fully relied upon in the scene, without the viewer being shown either Maggie in the diegetic space or the video monitor's content. The left-gliding, horizontal camera movement continues in a circular manner and turns right, making full use of the threedimensional cinematic space, including a more narrow shot of the reporter and the cameraman with his equipment in function, creating the mise-enabyme structure gluing together extracommunicational (in this case: cinematic) and intracommunicational (in this case: the video interview with Maggie) actual and virtual spheres (see Elleström 2018). As the small-talking, slightly embarrassed reporter announces "Maggie Cheung, take 1," a patch of greyishbluish texture covers the cinematic screen without transition, while another element of visual noise covers the video/televisual medium's message due to the malfunctioning of its medial apparatus. Maggie's frontal shot emerges from the shades in a desaturated, extremely close-up framing, revealing her microgestures of discomfort and unease, while connoting the video/televisual medium. Meanwhile, a back oblique shot of her, in full colour palette, reminds us of the cinematic possibilities. These are again, signalled by a left-gliding, horizontal and circular movement, which, after having shown in close-up a monologue of the reporter referring to John Woo's "masculine cinema," comes full circle, stopping on Maggie in a cinematic shot, highlighting the garish effect of her Irma Vep makeup in Paris daylight, suggesting the artificially constructed, exaggerated nature of this anything but modern and contemporary stylistics.

It is interesting to see how a decade changes this medium's connotations within the diegetic world. In Cronenberg's 1984 cult classic cable TV and video cassettes are a thing of the progressive future, with recklessly innovative, effective people (Bridey, Max Renn, Nicki Brand) using them, indeed, feeding on them. In Assayas's 1996 cult film cassettes and smaller frame television/electronic screens, as in the above analysed scene as well as a later party scene - where burned out French intellectuals watch a small monitor with low-resolution, showing supposedly revolutionary content -, are definitely a thing of the present which turns into past in front of our very eyes. 
The sequences when diegetic electronic screens are woven into the filmic narratives and within the diegetic space dramatize the barely palpable threshold(s) between what Lars Elleström names "mediation" respectively, "representation" (2014). While "mediation is a presemiotic phenomenon and should be understood as the physical realization of entities (with material, sensorial, and spatiotemporal qualities, and semiotic potential) that human sense receptors perceive within a communication context," like seeing a colour or hearing a sound (the examples of Elleström), on the other hand, "representation is a semiotic phenomenon and should be understood as the core of signification. [...] For instance, one may interpret the sound of a voice as meaningful words" (Elleström 2014, 12). Within this framework, the characters "looking at a [Manovich's] rectangular frame" - a hypnotic surface that "captures not only the gaze, but the mind in a way that reminds us of hypnosis" (Chateau 2016, 197), and which is characterized by a different scale than the first-level diegetic reality (Manovich 2001, 112) are in the process of "creating cognitive import," which goes beyond or above "human sense receptors' [perception]" (Elleström 2014, 12). For the actual (cinematic) viewer of Videodrome or Irma Vep, therefore, the televisual and the video medium/screen becomes fully perceivable and visible, actually forming/ constituting the message of the cinematic medium/screen.

In David Lynch's 1997 Lost Highway, the ominous video cassette left on the villa staircase definitely presents a differently-scaled virtual world, hypnotically capturing its diegetic and actual viewers's attention. The content of the cassette and the television screen is full with visual glitches and auditive noises that often cover the whole cinematic screen. As if an effect of the noiseful video/televisual medium, in Lost Highway most prominently the whole cinematic screen becomes blurred and is covered with non-figurative patches of light, reminding of Florian Cramer's observation: "the characteristics of any medium only reveal themselves in its misbehavior at the low end" (2013). However, as other similar examples from Videodrome or Irma Vep suggest, this method does not make room for Manovich's "simulation tradition," ${ }^{\circ}$ where the viewer can move freely, as would

5 The fundamental characteristic of the screen and its frames formulated by Lev Manovich back in 2001, in The Language of New Media is that it "separates two spaces that have different scales - the physical and the virtual. Although this condition does not necessarily lead to the immobilization of the spectator, it does discourage any movement on her part" $(2001,112$, emphasis in the original).

6 "The simulation tradition aims to blend virtual and physical spaces rather than to separate them. Therefore, the two spaces have the same scale; their boundary is de-emphasized (rather than being marked by a rectangular frame, as in the representation tradition); the spectator is free to move around the physical space.” (Manovich 2001, 112). 
be the case in virtual reality-type representations, for example. Rather, noise is introduced to (re)present the cinematic medium, "un-aisthecizing it" - to use Krämer's thesis. "The implementation of media depends on their withdrawal. I will call this 'aisthetic self-neutralization'. It is important to note that this neutralization belongs to the functional logic of media. It is not an inherent feature of the medium itself, but rather it only takes effect when media are in use. The invisibility of the medium - its aesthetic neutralization - is an attribute of media performance." (Krämer 2015, 31.)

\section{Closing Remarks}

Thus, to conclude, I propose that one function of the introduction of diegetic, smaller-format electronic screens within cinematic fictive world and spaces is that of generating noises pertaining to the video, the televisual, and indeed, the cinematic medium, thus offering the possibility of their contemplation by the actual (cinematic) spectator. The examined sequences where/when diegetic electronic screens are scattered within the fictive spaces are aiming for non-neutralizing the medium/ media involved, making it/them visible primarily not for the diegetic spectator, but rather (for) the actual viewer - thus offering us the cognitive representational models referring to medium specificity. Torben Grodal's observation also points into this direction: "the use of technical devices to represent these processes in an intersubjective form makes the mental processing visible; the gadgets are real, but they are also an extension of the way normal perception and cognition work, and are therefore mental models of perception and cognition" $(1997,242)$.

As already suggested in the introductory part, the multiscreen problematic presented in this article may be considered a subcase of Gerard Genette's model of the co-existence of first-order narratives and various metadiegetic levels. As a matter of fact, the framing processes evoked apropos the functioning of diegetic electronic screens - in this analysis television and video - recall Genette's wonderful examples of metalepsis, or "the changes of level in the Robbe-Grillet type of narrative (characters escaped from a painting, a book, a press clipping, a photograph, a dream, a memory, a fantasy, etc.)" (1983, 235-236). Derrida's idea - that a frame "labours [travaille] indeed. Place of labor, structurally bordered origin of surplus value, i.e., overflowed [debordée] on these two borders by what it overflows, it gives [travaille] indeed" $(1987,75)$ - appears as truly pertinent in the case of the examined diegetic electronic screens, which introduce frames and edges in the diegetic worlds as constitutive backgrounds. 


\section{References}

Bolter, Jay David and Richard Grusin. 2000 [1999]. Remediation. Understanding New Media. Cambridge, MA, London, England: MIT Press.

Bruno, Giuliana. 2014. Surface: Matters of Aesthetics, Materiality, and Media. Chicago and London: University of Chicago Press.

Chateau, Dominique. 2016. Between Fascination and Denial: The Power of the Screen. In Screens. From Materiality to Spectatorship - A Historical and Theoretical Reassessment, eds. Dominique Chateau and José Moure, 186-199. Amsterdam: Amsterdam University Press.

Cramer, Florian. Post-Digital Aesthetics. Le Magazine Jeu de Paume, May 1, 2015. http://lemagazine.jeudepaume.org/2013/05/florian-cramer-post-digitalaesthetics/. Last accessed 19. 07. 2019.

Derrida, Jacques. 1987. The Truth in Painting. Chicago and London: The University of Chicago Press.

Enns, Anthony. 2015. Introduction: The Media Philosophy of Sybille Krämer.

In Sybille Krämer: Medium, Messenger, Transmission. An Approach to Media Philosophy, 9-18. Amsterdam: Amsterdam University Press.

Elleström, Lars. 2014. Media Transformation:The Transfer of Media Characteristics among Media. Houndmills, Basingstoke: Palgrave Macmillan.

Elleström, Lars. 2018. Coherence and Truthfulness in Communication: Intracommunicational and Extracommunicational Indexicality. Semiotica 225: 423-446.

Elsaesser, Thomas. 2016. Film History as Media Archaeology: Tracking Digital Cinema. Amsterdam: Amsterdam University Press.

Gaudreault, André and Philippe Marion. 2015. The End of Cinema? A Medium in Crisis in the Digital Age. New York: Columbia University Press.

Genette, Gerard. 1983. Narrative Discourse: An Essay in Method. Ithaca, New York: Cornell University Press.

Grodal, Torben. 2002 [1997]. Moving Pictures. A New Theory of Film Genres, Feelings and Cognition. Oxford: Clarendon Press.

Johnston, John. 1997. Friedrich Kittler: Media Theory after Poststructuralism. In Friedrich A. Kittler: Literature, Media, Information Systems. Essays, ed. John Johnston, 1-26. Amsterdam: G+B Arts International.

Kittler, Friedrich A. 1997. The World of the Symbolic - A World of the Machine. In Literature, Media, Information Systems. Essays, ed. John Johnston, 130-146. Amsterdam: G+B Arts International. 
Krämer, Sybille. 2015. Medium, Messenger, Transmission. An Approach to Media Philosophy. Amsterdam: Amsterdam University Press.

Manovich, Lev. 2001. The Language of New Media. Cambridge, Massachusetts London, England: The MIT Press.

Odin, Roger. 2016. The Concept of the Mental Screen: The Internalized Screen, the Dream Screen, and the Constructed Screen. In Screens. From Materiality to Spectatorship - A Historical and Theoretical Reassessment, eds. Dominique Chateau and José Moure, 176-185. Amsterdam: Amsterdam University Press.

Persson, Per. 1999. Understanding Representations of Space: A Comparison of Visualisation Techniques in Mainstream Cinema and Computer Interfaces. In Social Navigation of Information Space, eds. Alan J. Munro, Kristina Höök and David Benyon, 195-218. Springer PH.

Sobchack, Vivian. 2000 [1990]. The Scene of the Screen: Envisioning Cinematic and Electronic "Presence." In Film and Theory: An Anthology, eds. Robert Stam and Toby Miller, 66-84. Malden: Blackwell Publishers.

Strauven, Wanda. 2016. The Screenic Image: Between Verticality and Horizontality, Viewing and Touching, Displaying and Playing. In Screens. From Materiality to Spectatorship - A Historical and Theoretical Reassessment, eds. Dominique Chateau and José Moure, 143-156. Amsterdam: Amsterdam University Press.

Virginás, Andrea. 2007. A múlt egy képernyő? Az elsőszintú diegézis megnyitása médiumok közbeiktatása révén [The Past is a Screen? Fracturing the Diegesis through Other Media]. In Film, Kép. Nyelv [Film. Image. Language], ed. Pethő Ágnes, 259-275. Cluj-Napoca: Scientia.

Virginás, Andrea. 2015. Screens “as Representation” and Screens "as Simulation” in Mainstream Cinema Detection: between Blade Runner (1982) and Splice (2009). The Nordic Journal of Aesthetics vol. 24, no. 47: 76-93.

Virginás, Andrea. 2017. Gendered Transmediation of the Digital from S1m0ne to Ex Machina: "Visual Pleasure" Reloaded? European Journal of English Studies vol. 21, no 3: 288-303.

Virginás, Andrea. 2018. On the Role of Diegetic Electronic Screens in Contemporary European Cinema. Acta Universitatis Sapientiae: Film and Media Studies vol. 15, no. 1: 87-102. 